\title{
İslam Meşşâî Felsefe Geleneğinde Metodik İlkeler ve Değeri*
}

\section{Methodical Principles and It's Values in the Tradition of Islamic Peripatetic Philosophy}

\begin{abstract}
(iD) Kemal Sözen
Akdeniz Üniversitesi, Türkiye

kemalsozen37@gmail.com

Geliş Tarihi: 10 Ekim 2019

Kabul Tarihi: 15 Kasım 2019

Yayın Tarihi: 28 Ocak 2021

Öz: Metot ile gerçek bilginin elde edilmesi arasında mutlak bir ilişki vardır. Dolayısıyla gerçek bilgiyi keşfetmek ve bu konuda istenilen neticeye ulaşmak, metot ile ilgili bazı ilkelerin varlığını zorunlu kılar. Bu sebepledir ki her filozof düşüncesini sistematik bir tarzda inşa ederken belli başlı metodik ilkeler çerçevesinde hareket eder. Benzer şekilde, İslam Meşşâi felsefe geleneğine mensup Kindî, Farabî, İbn Sina ve İbn Rüşd gibi düşünürler de metot ile ilgili bazı ilkeleri esas almışlardır. Felsefî düşünce sistemlerini ise benimsedikleri ilkelere bağlı kalmak suretiyle inşa etmişlerdir. Bu çalışmada öncelikle metot kavramı ele alınıp, metodun bilgi edinme sürecindeki önemi üzerinde durulacaktır. İsimleri zikredilen Meşşâi filozofların gerçek bilgiye ulaşmak için hangi ilkeleri esas aldıkları incelenecektir. Onların benimsemiş oldukları söz konusu ilkelerin günümüz açısından ifade ettiği anlam ve öneme işaret edilecektir.
\end{abstract}

Anahtar Kelimeler: Metot, Metodik Illkeler, Peripatetik Felsefe, Bilgi Edinme, Te'vil

\begin{abstract}
There is an absolute relationship between the method and the acquisition of real knowledge. Therefore, discovering real knowledge and getting the desired results requires the existence of some methodical principles. For this reason, while each philosopher built his or her ideas in a systematic manner, act in accordance with same certain methodical principles. Similarly, al-Kindî, al-Farabî, Ibn Sinâ and Ibn Rushd who belong to the tradition of Islamic Peripatetic philosophy based on some methodical principles. Also they built their systems of philosophical thought according to the principles which they adopted. In this study, firstly, we will focus on the concept of the method and its importance while acquiring knowledge. And we will examine principles which the Peripatetic philosophers based on to acquire real knowledge. Lastly, we will indicate Peripatetic philosopher's principles in terms of its meaning and significance today.

Keywords: Method, Methodical Principles, Peripatetic Philosophy, Acquiring Knowledge, Ta'wil

ORC-ID: K. Sözen 0000-0002-2575-5093

* Bu çalışma İbn Haldun Üniversitesi tarafından 20-21 Aralık 2019 tarihinde İstanbul'da düzenlenen "Uluslararası İslam'da Medeniyet Bilimleri Tarihi Sempozyumu" adlı bilimsel etkinlikte sunulan bildirinin gözden geçirilmiş halidir.
\end{abstract}




\section{Giriş}

Kültürlerin oluşması ve medeniyetlerin inşasında bilim ve felsefe önemli bir konuma sahiptir. Zira medeniyet, insanın başta inanç, bilim, felsefe, sanat ve estetik olmak üzere çeşitli alanlardaki etkinliklerinin bir yansımasıdır. Meseleyi daha özele indirgersek, İslam medeniyetinin oluşumunda sistemli bir şekilde ve bilimsel metotlarla bilgi üretilip bir disiplin haline getirilmesi sonucu teşekkül eden bilimlerin payı büyüktür. Fakat gerek bilgi edinme süreci gerekse elde edilen bilgi birikimlerinin sistematik hale getirilip belli bir disiplin niteliğini kazanması birtakım metodik ilkeleri zorunlu kılar. İnsanın ise gerçek bilgiye ulaşabilmesi için bilgi edinimi açısından belli bir yetkinliğe ulaşması gerekir. Bunun yanı sıra bilimsel açıdan hedeflenen amacın gerçekleştirilebilmesi için gerekli olan stratejiler bütününü ifade eden metot bilgisi şarttır. Çünkü insanın kültürel hayatının bir gereği olan gerçeğe ulaşma çabası, çeşitli metodik ilkeler çerçevesinde hareket edilmesi halinde beklenen müspet sonuçları verir.

Birbiriyle alâkalı bilimleri gruplandırma amacıyla gerçekleştirilen İslam bilimler tasnifi içinde yer alan gerek aklî (felsefî/hikemî) gerekse naklî (şer'î/dinî) disiplinler alanında fikir üreten düşünür ve bilginler, bilimsel araştırmalarını gerçekleştirirken bazı metodik ilkeleri esas alıp bu doğrultuda hareket etmişlerdir. Keza İslam felsefe geleneğinde en yaygın etkiye sahip olan Meşşâî ekole mensup Kindî (öl. 866?), Farabî (öl. 950), İbn Sina (öl. 1037) ve İbn Rüşd (öl. 1198) gibi filozoflar da birtakım metodik ilkeleri benimseyip kullanmak suretiyle felsefî düşünce sistemlerini inşa etmişlerdir.

Metodik ilkeler ile ilgili görüşlerini ele alacağımız Kindî, Farabî, İbn Sina ve İbn Rüşd'ün mensup olduğu Meşşâillik, kelime anlamı itibarıyla "yürüyücülük" demek olup, bu akımı temsil eden İslam filozofları Aristoteles doktrinini benimserler. Bundan dolayı onlara "yürüyenler" anlamında Meşşâiyyûn denir. Yaygın anlayışa göre Aristoteles (m.ö. 384322) zihin ve beden jimnastiğini aynı anda yaptırmak amacıyla Atina'da Lykeion (Lise) adıyla kurmuş olduğu felsefe okulunda derslerini okulunun geniş revakları arasında gezinerek vermiştir. Bu bakımdan onun felsefesine Yunanca "gezinmek, yürümek" anlamındaki peripatein masdarından hareketle Peripatetizm ismi verilmiştir. Mezkûr kavram tercümeler döneminde Arapçaya Meşşâiyye olarak tercüme edilmiştir (Kaya, 2004: 393). Her ne kadar Meşşâillik, Aristocu felsefeye nispetle isimlendirilmiş olsa da, bu akım tam anlamıyla Aristoteles'in fikirlerini benimsemiş değildir. Zira Meşşâî ekole mensup düşünürler temel problemlerde İslamî öğretiye uygun hareket etmişler; bununla birlikte birtakım yorum ve açıklamalarında Aristoteles'in yönteminden faydalanmışlardır. Aristoteles'ten esinlendikleri gibi, Platon (m.ö. 427-347) ve Yeni Platonculuktan da yararlanmışlardır. Mantık sahasında Aristoculuk daha etkili iken; 
metafizik, siyaset ve ahlak alanlarında ise Platonculuk ve Yeni Platonculuk akımlarının etkisi oldukça belirgindir. Bu bakımdan Meşşâî felsefe geleneği sadece Aristoteles'in düşüncelerinden esinlenerek oluşturulmuş bir felsefe akımı değildir. Dolayısıyla Meşşâilik, eklektik nitelik taşıyan bir düşünce etkinliğidir (Bayrakdar, 2011: 102-103).

Daha önce "Kindî'nin Metot Anlayışı" başlığıyla yayınlanan bir makalemizde (Sözen, 2005: 21-31) Kindî ile sınırlı tuttuğumuz metot konusunu, genel olarak Meşşâî felsefeyi kapsayacak tarzda genişletmek suretiyle farklı bir sistemle yeniden ele alıp değerlendirmeyi amaçladığımız bu çalışmada, öncelikle metot kavramı hakkında kısaca bilgi verilip önemi üzerinde durulacaktır. Diğer taraftan metodun bilgi edinme sürecindeki fonksiyonu irdelenecektir. Ardından da Kindî, Farabî, İbn Sina ve İbn Rüşd olmak üzere Meşşâî felsefe geleneği içinde yer alan filozofların metot ile ilgili sundukları birtakım ilkelere yer verilip analiz edilecektir. Çünkü onların, farklı bilimlere ait bilgi birikimlerini sistematik bir şekilde öğrenip değerlendirebilmenin hangi yöntemlere bağlı olduğu konusundaki görüşleri önem taşımaktadır. Geçmişin düşünce ürünlerinin gelecekte gerçek bilgiye ulaşma bağlamında bir araç konumunda olduğu gerçeği dikkate alınarak isimleri mezkûr düşünürlerin günümüz dünyasına sundukları metodik ilkelerin doğru algılanıp gereği gibi hareket edilmesinin pratik değerine vurgu yapılacaktır.

\section{Metot ve Bilgi Edinme Sürecindeki Önemi}

Metot (usûl, tarîk), "Belli bir neticeye ulaşmak ve özellikle de hakikati keşfetmek için düşünceyi yönlendiren çeşitli yöntemlerdir." (İsmail Fenni, 1341: 420). Diğer bir tanımlamaya göre de metot (menhec/minhec), "Gizli bir hakikati bulup ortaya çıkarmak veya bilinen bir hakikati ispat etmek için izlenecek olan kuralların veya kullanılacak olan vasıtaların tümüdür." (İsmail Hakkı, 1329: 11).

Görüldüğü üzere metot, bilinmeyeni ortaya çıkarabilmek ya da bilineni başkalarına kanıtlayabilmek için düşünceleri belli bir sıraya göre kullanmayı kapsayan zihinsel bir süreci içerir. Insan gerek bir gayeye ulaşmayı hedeflesin gerekse gerçeği bulup ortaya çıkarmaya çalışsın, her iki durumda da belli bir metodu izlemek zorundadır. Aksi durumda arzu edilen neticeyi elde etmeye muvaffak olamaz. İşte bu hususta takip edilecek kuralların veya kullanılacak vasıtaların tümü metot olarak adlandırılır. Metot ise her bilimin temel şartıdır (İsmail Hakkı, 1329: 11).

İçinde yaşadığı âleme kayıtsız kalamayan insan kendisini kuşatan varlık âlemini tanımak ister. Onun varlık ve olayları tanıyıp anlama çabası belli bir zaman sürecini 
gerektirir. Fakat insan ömrünün sınırlı olduğu dikkate alındığında bu eylemin zamansal bakımdan hızlı ve güvenle gerçekleştirilmesi zorunluluğu ortaya çıkar. Varlık ve olayları çabuk ve sağlam bir şekilde kavramayı sağlayan birtakım yollar mevcuttur. Dolayısıyla metot, insanın hakikati bulmak ve onu ispatlamak amacıyla başvurduğu yolların tümüdür. Bu bakımdan geçmişin bilgi birikimi ve deneyimlerinden istifade etme zorunluluğu söz konusudur. Çünkü en güçlü zekâların bile yüzyılların birikimi olan denemelerle oluşturulmuş sağlam metotlardan habersiz kalması halinde tehlikeli yollara sapmaktan ve telafisi zor olan yanlışlara düşmekten kurtulmaları zordur. Gemiyi insan zihnine, dümeni ise metoda benzetmek suretiyle bir analoji yapmak gerekirse, nasıl ki fırtınalı bir havada bindikleri gemiyi dümenden anlayan birine teslim etme zorunluluğunu hissetmeyen insanların korkunç bir akıbete uğramaları kaçınılmaz ise, metot bilgisine sahip olmayan kimselerin de hakikati bulma ve ispatlama hususundaki karşılaşacakları durum benzer şekildedir. Metodun önemini bir karşılaştırma yapmak suretiyle de ortaya koymak mümkündür. Örneğin, zekâ bakımından orta seviyede olmasına rağmen metoda dayalı hareket eden bir kimse ile metotsuz çalışan üstün zekâlı birinin ulaşacakları sonuç farklılık gösterir. Çünkü orta seviyede zekâya sahip olan bir kimse, metodu esas aldığı için gerçek bilgilere ulaşabilir. Fakat zikredilen niteliğe sahip diğer kişinin ise doğru bilgileri elde etmesi mümkün değildir (Yücel, 1948: 73).

Görüldüğü üzere bilimsel bilginin elde edilmesinde metot son derece önemlidir. Zira gerçeği aramanın yolu ve yöntemi metottur. İslam felsefesinde metoda ilişkin ilk denemeyi gerçekleştiren Kindî, metodun insana gerçeğe ulaşmak için yol gösterdiğini, kişiyi bilgisizliğin karanlığından ve şüphelerin yol açtığı sıkıntılardan kurtardığını belirtir. Onun akıl gözünü aydınlatan âdeta bir meşale olduğunu söyler (Kindî, 2014a: 133).

İslam felsefesinin önemli temsilcilerinden biri olan Farabî'ye göre, bir mesele hakkında araştırma yapılması sonucu insanda o probleme dair akıl yürütme veya öğrenim yoluyla bilgi ve düşünce hâsıl olur. Her meselenin incelenmesindeki asıl maksat, gerçek bilgiyi elde etmektir. Fakat bu hususta burhanî, hitabî ve cedelî gibi çeşitli metotların bilinmesi gerekir. O halde herhangi bir bilimsel araştırmaya başlamadan önce gerekli metot bilgisine sahip olmak şarttır. Bu açıdan her bir metodun özelliklerini bilmek suretiyle onları birbirinden ayırt edebilecek bilgi seviyesine erişmek bir zorunluluktur. Bunun için de doğuştan gelen bir yeteneğe sahip olmak gerekir. Diğer taraftan hangi metodun ne tür bir alanda kullanılacağı bilgisi de önem taşır (Farabî, 2012: 22-23; 1974: 4-5). 
Yeniçağ felsefesinin kurucusu René Descartes (1596-1650) metoda bağlı hareket etme konusuna dikkat çeker. Ona göre hakikati metotsuz aramaktansa hiç aramamak daha hayırlıdır. Çünkü düzensiz araştırmalarla ortaya çıkan belirsiz düşünceler tabiat ışığını karartır ve düşünceyi köreltir. Karanlıklar içinde yürümeye alışanların gözlerinin keskinliği azalır; sonuçta Güneş ışığına dayanamaz bir konuma gelirler (Descartes, 1997: 15).

\section{Bilgi Edinmede Metodik İlkeler}

Meşşâî ekole mensup filozoflar, felsefî düşüncelerini sergilerken metoda ilişkin bazı ilkeleri de zikretmişlerdir. Bu çerçevede mezkûr ekolün kurucusu Kindî, muhtelif eserlerinde metot ile ilgili birtakım görüşler serdetmiştir. Dolayısıyla Kindî'nin metoda dair görüşlerinin, mezkûr ekolün metot anlayışının şekillenmesinde önemli bir payı vardır. Diğer taraftan onun Meşşâi ekolün ilk temsilcisi olması hasebiyle metodik görüşleri bir değer ifade eder. Çünkü Kindî'nin metotla ilgili sergilediği görüşlerinin kendinden sonraki bazı düşünürlerde de etkileri görülmektedir (Sözen, 2005: 21).

Metot ile bilgi edinme arasında mutlak bir ilişki vardır. Bu bakımdan bilginin elde edilmesinde bazı metodik ilkeler mevcuttur. Şimdi bunlara yer verelim.

\subsection{Ulaşılmak İstenen Gayeyi Belirleme}

Kindî'ye göre insanın bilgi açısından neyi nereden ve nasıl elde edeceği ve yeni birtakım bilgilere hangi ölçütlere bağlı olarak ulaşacağı metot bilgisini zorunlu kılar. Bilgi edinme sürecinde öncelikle ulaşılmak istenen hedefin belirlenmesi gerekir. Zira ulaşmak istediği gayeyi bilen insan, gücünü ve düşüncesini o yönde yoğunlaştırdığı takdirde hiçbir engel onu hedefe ulaşma isteğindeki kararlılığından geri döndüremez. Nitekim gayesini gerçekleştirmek için ciddi ve sağlam adımlar atar. Bu durumun kendisini belirlenen hedefe daha çok yaklaştırdığını bilir. Ne var ki onu gayesinden saptıracak birtakım zan ve tereddütler akla gelebilir. Fakat düşünce ve eylem birlikteliği içinde gayesi doğrultusunda kararlı ve sürekli bir şekilde hareket eden kimsenin hata yapma ihtimali ortadan kalkar. Ulaşmak istediği gayeyi bilmeyen kimse ise ona ulaşmış olmasına rağmen onu tanıyamaz. Bu durumda da ondan yararlanması mümkün değildir (Kindî, 2014b: 279-280). O halde belli bir alanda bilgi elde etmek isteyen kimse öncelikle gayesini belirlemeli ve bu doğrultuda hareket ederek sonuca odaklanmalıdır.

\subsection{Geçmişin Bilgi Birikimlerinden Yararlanma}

Bilgi edinme sürecinde önemli metodik ilkelerden bir diğeri de geçmişin bilgi birikimlerinden yararlanmaktır. Zira Meşşâi ekole mensup bazı filozoflar, hak ve 
kadirbilirlik vasfının bir yansıması olarak birey ve toplumların gerçek adına elde ettikleri birikimlerin değer taşıdığını ısrarlı bir şekilde vurgulamışlardır. Örneğin Kindî, bize gerçeği büyük ölçüde getirenlerin yanı sıra basit ve küçük oranda ulaştıranlara da teşekkür borcumuzun olduğunu belirtir. Ona göre geçmişte yaşayan düşünür ve bilginler gelecek nesilleri üretmiş oldukları bilgi birikimlerine ortak etmişlerdir. Şayet onların bilgi birikimleri olmasaydı, yoğun olarak çalışılsa bile doğru öncüllerden hareket ederek sonuç çıkarılıp bilinmeyene ulaşmak imkânsız olurdu. Dolayısıyla mevcut bilgi birikimi geçmiş dönemlerden günümüze kadar süregelen yoğun ve emek mahsulü çalışmaların bir neticesidir. Öyle ki, bir insanın ömrü uzun, çalışması ciddi ve yoğun, zihinsel bakımdan ne kadar güçlü olursa olsun, bu tür bir bilgi birikimini hayatı boyunca elde etmesi düşünülemez. Bu bakımdan hangi ölçüde olursa olsun, bilgilerinden istifade ettiğimiz kimseleri karalayıp onları yok saymamak gerekir. Onlardan bize tevarüs eden ürünler, onların hakikatine vâkıf olamadıkları bilgiye ulaşmak için bir yol ve vasıta niteliği taşır. Zira bir birey ya da topluluk sırf kendi çabası sonucu mutlak bilgiye ulaşamaz. Birtakım bilgiler elde edilse bile, gerçekle kıyaslandığında bunlar kısmî bir nitelik taşırlar (Kindî, 2014a: 127-128).

Görüldüğü üzere Kindî, bir bilim insanının bilgi edinme sürecinde nasıl bir tavır sergileyeceğinin altını çizer. Geçmişten bugüne gerçek bilgiyi ulaştıranlara saygı duyulmasını ve ilmî taassuba yer olmadığını vurgular.

Meşşâî felsefe geleneğinin Batı İslam dünyasındaki (Endülüs) önemli temsilcisi İbn Rüşd de bilgi edinme sürecinde geçmişin bilgi birikimlerinden yararlanma ilkesi ile ilgili Kindî'nin düşünceleriyle örtüşen nitelikte görüşler ortaya koyar. Zira İbn Rüşd, insanın bireysel olarak bir bilimi teşekkül ettirmesinin imkânsız olduğunu vurgular. Bu hususun bütün bilim dalları için geçerli olduğunu ifade eder. Çünkü ona göre bir kişinin tek başına ortaya çıkarabileceği herhangi bir bilim dalı söz konusu değildir. Bu nedenle geçmiş milletlerde burhan şartlarının gerektirdiği tarzda bir araştırma ve değerlendirmeye rastlanıldığı takdirde bunlar dikkate alınmalı, dolayısıyla incelenip değerlendirilmelidir. Bunlardan hakikate uygun olanlar kabul edilmelidir. Günümüze intikal eden bu bilgilerden dolayı sevinç duyulmalıdır. Hatta bilgi sahiplerine teşekkür edilmelidir. Fakat hakikate uygun olmayan bilgilere dikkat çekilmeli, başkalarını onlardan sakındırma yoluna gidilmelidir (ibn Rüşd, 1986a: 32-33; 1992: 71-72).

Kindî ve İbn Rüşd'ün gerçek bilgileri gelecek nesillere miras bırakan kimselere teşekkür edilmesi gerektiği yönündeki düşüncelerinin Aristoteles'in bu konudaki fikirleriyle örtüştüğü görülmektedir. Zira Aristoteles, sadece görüşleri paylaşılan kişilere değil, yüzeysel bilgiler ortaya koyan kimselere de minnettar olmak gerektiğini belirtir. Çünkü 
onların, kendinden sonraki nesillerin düşünme yetilerini geliştirmelerine katkı sunduklarını ifade eder (Aristoteles, 1985: 993 , 149-150).

Bilgi ediniminde metodik ilkeler çerçevesinde hareket edilmesinin önemini belirten İbn Rüşd, bir araştırma için geçmişte ortaya konulmuş bilgi birikimlerinin dikkate alınmasının yanı sıra önceki filozofların ileri sürmüş oldukları şartlara ve inceleme için gerekli gördükleri kurallara uymanın gerekliliğini vurgular. Bunun yanı sıra o, bir kimsenin gerçeği bilen kişilerden olmayı istemesi durumunda araştırma yaptığı her konuda ileri sürülen çeşitli görüşleri de göz önünde bulundurmak zorunda olduğunu söyler. Dolayısıyla İbn Rüşd, araştırma sürecinde asıl kaynağa gitmenin önemini vurgulayarak gerçek bilginin ancak bu şekilde elde edilebileceğini ifade eder (İbn Rüşd, 1986b: 100).

\subsection{Bilimsel Açıdan Taassuptan Uzak Durma}

Düşünür İbn Rüşd'e göre, herhangi bir bilim alanına giren konularda daha önceden araştırma yapılmamış ise, öncelikle yapılması gereken araştırmalara başlanmalı, meselenin eksiksiz bir şekilde çözümlenmesi için geçmişte fikir üreten bilim insanlarının görüşlerinden yardım alınmalıdır. Zira bir kimsenin ilk defa araştırma yapılacak konuyla ilgili tek başına her şeyi üstlenmesi zor, hatta imkânsızdır. Öyleyse araştırma sürecinde geçmişte yaşamış olan araştırmacıların bilgilerine başvurmak bir zorunluluktur. Bu hususta bilgi ve tecrübelerinden yararlanılan kimselerle aynı dine mensup olmak da gerekmez. İbn Rüşd, meseleyi kurban kesme örneğiyle açıklığa kavuşturur. Ona göre kurban kesmeye elverişli bir alet (bıçak) bulunduğu takdirde onunla kurban kesmenin dinî bakımdan geçerli olması için kullanılan aletin sahibiyle aynı dinin paylaşılıp paylaşılmaması itibara alınmaz. Burada ölçü, onda kurban kesmek için gerekli şartların bulunmasıdır. Şayet bir konuda geçmiş milletler en mükemmel şekilde araştırma gerçekleştirmişler ise onların kitaplarını ele alıp ortaya koydukları görüşlere bakılmalı, gerekli değerlendirmeler yapılmalıdır. Bütün doğrular kabul edilmeli, şayet yanlışlar varsa onlara da dikkat çekilmelidir (ibn Rüşd, 1986a: 31-32; 1992: 68-69).

Görüldüğü üzere İbn Rüşd, bilimde bağnazlığa ve dogmatizme yer olmadığını açık bir şekilde ortaya koymuştur. O, gerçeğe ulaşma yolunda yanılmış olsalar bile ortaya koymuş oldukları bilgi ve görüşlerinden yararlanılan herkese şükran duyulması gerektiği fikrini benimseyerek tarafsız olmayı, objektif davranmayı, her türlü görüş ve düşünceye saygı duymayı, fakat daima ihtiyatla hareket etmeyi ilke edinmiştir (Sarığlu, 2003: 26-27). 
Her ne kadar Kindî ve İbn Rüşd'ün geçmişin bilgi birikimlerinden yararlanma ve bilimsel açıdan taassuptan uzak durma hususundaki fikirlerinin oluşumuna Aristoteles'in tesir ettiği anlaşılsa da esasen bu konuda İslam'ın bilime verdiği önemin çok daha etkili olduğu söylenebilir. Zira isimleri mezkûr filozofların Müslüman kimlikleri göz önünde tutulursa onların İslam'ın bilime ve bilim insanına verdiği değeri dikkate almamaları düşünülemez. Çünkü İslam, bilim elde etmeyi teşvik eder. Gerçek bilginin elde edilmesinde kaynak itibarıyla herhangi bir ırk, millet ve din sınırlaması yapmaz. $\mathrm{Hz}$. Peygamber'in bu konudaki uygulamalarının yanı sıra bazı öğütleri de mevcuttur. Zira Hz. Peygamber, "ilim ve hikmet mü'minin yitiğidir. Her nerede bulursa alır." (Tirmizî, 1981: İlim, 19; İbn Mâce, 1981: Zühd, 17) ve "ïlim Çin'de bile olsa alınız." (Beyhakî, 2013: 193) buyurmaktadır.

\subsection{Tenkit ve Değerlendirmeleri Objektif Ölçütlere Göre Yapma}

Bilimlerin gelişmesinde objektif ölçütlere göre yapılan tenkidin önemli derecede payı vardır. Fakat dildeki yanlış anlaşılmanın bir sonucu olarak tenkide karşı menfi bir tavır takınılmıştır. Herhangi bir konuda tenkit yapılacaksa amacının ve sınırlarının çok iyi tespit edilmesi gerekir. Bu bakımdan ele alınan konu iyice araştırılıp analiz edilmeli, gerekli kontroller yapıldıktan sonra yorumlama cihetine gidilmelidir. Tenkit aşamasında bilimsel ölçütlerden uzak kalınmamalı, subjektif yaklaşımlardan kaçınılmalıdır. Çünkü bu husus bilim ahlakı açısından önem taşır.

Düşünür Kindî, her şeyden önce hakikat kavramını merkeze alarak, bunun kaynağının kim ve ne olduğunun bir anlam ifade etmediğini vurgular. Ona göre hakikat hangi milletten gelirse gelsin, gerçeği benimsemekten ve ona sahip olmaktan kaçınılmamalıdır. Çünkü gerçek bilgiyi arayan için ondan daha değerli bir şey söz konusu değildir. Öyleyse mutlak gerçek niteliğine sahip olan bilgiler eksik olarak değerlendirilmemeli, onları ortaya koyanlar ve nakledenler küçümsenmemelidir. Ele alınan konular incelenirken geçmişte ilgili konularda eser kaleme almış kimselerin görüşleri eksiksiz bir şekilde olduğu gibi verilmelidir. Kindî, gerçekleştirilen araştırma sürecinde titiz davranmanın yanı sıra dilin yapısı ve dönemin anlayışının da dikkate alınmasının gerekli olduğunu zikreder. Onun dikkat çektiği diğer bir husus ise, yeterli zekâ düzeyine sahip olmayan ve gerekli bilgi birikimini elde edemeyen kimselerin hakikati aramada aciz kalacak olmalarıdır. Ona göre mezkûr nitelikteki insanlar bilimsel bakımdan üst seviyede olan düşünce sahiplerini takdir etmezler. Ayrıca içtihat yapma yetisine de sahip değildirler. Onların kıskançlık duyguları ve basiretsiz oluşları gerçeğin aydınlığını görmelerini engeller. Dahası, saldırgan ve düşmanca bir tutum izlerler. Elde ettikleri konumlarını korumak için kendilerinin yoksun olduğu ve onlara çok uzakta 
olan insanî erdemlere sahip olan kişileri aşağılama gibi olumsuz bir davranış biçimi sergilerler (Kindî, 2014a: 128-129).

Görüldüğü üzere Kindî, hakikat niteliğine sahip bilgileri objektif bir şekilde değerlendirmenin gereğini vurgular. Bilgi donanımı bakımından yetersiz kimselerin subjektif bir tavır sergileyeceklerini belirtir.

İbn Rüşd ise bir araştırmada kişiyi yanlış değerlendirmeye sevk eden birçok etkenin bulunduğunu belirtir. Ona göre insanı yanılgıya sürükleyen etkenler; yaratılıştan gelen eksiklik, metot hatası, arzu ve eğilimlerin baskın gelmesi, meseleyi anlayıp değerlendirebilecek düzeyde yeterli eğitim alınmayışı gibi hususlardır. Bir kimse mezkûr sebeplerin birkaçının veya hepsinin bir araya gelmesi nedeniyle bir konuyu (felsefe) inceleyip değerlendirme yaptığında yanılgıya düşmüş ise bu kişiyi göz önünde bulundurup diğer yetkin kimselerin araştırma ve değerlendirme yapmalarını engellemek doğru bir yaklaşım değildir. Çünkü yanılgıya düşen kişiye ilişen zarar arazîdir. Doğası gereği yararlı olan bir şeyin arazî bir zarardan dolayı terk edilmesi gerekmez. Örneğin, bilgi yönünden yetersiz kimselerin felsefeyle ilgilenmeleri sonucunda onların sapıttıkları zannedilebilir. Bundan dolayı da hikmet kitapları yasaklanabilir. Fakat bu husus tıpkı su içerken suyun boğazı tıkaması nedeniyle ölen bir kimseyi göz önünde bulundurarak susamış olan birini tatlı ve soğuk su içmekten alıkoymak gibidir. Çünkü suyun boğazı tıkamasından dolayı ölmek ârızî, susuzluk sebebiyle hayatın sonlanması ise zâtî ve kaçınılmaz bir durumdur (İbn Rüşd, 1986a: 33; 1992: 72-73).

İbn Rüşd'e göre bir araştırmacı ele aldığı mesele hakkında karşıtlarının delillerine yer verirken özen göstermelidir. Dolayısıyla onları sanki kendi delilleriymiş gibi ortaya koymalıdır. Araştırma sürecinde ileri sürdüğü kendi delilleriyle ilgili gösterdiği çaba ve özeni, karşıtlarının delilleri hakkında da göstermeye gayret etmelidir. Onların delillerini âdeta kendi delilleri olarak görmelidir (İbn Rüşd, 1986b: 121).

Tenkit ve değerlendirmelerinde İbn Rüşd'ün bütüncül bir bakış açısını dikkate aldığı söylenebilir. O, tenkitlerini yöneltirken bütün ihtimalleri göz önünde bulundurarak birtakım değerlendirmeler yapar. Örneğin İbn Rüşd, Gazzalî'nin Tehâfütü'l-felâsife adlı eserinde meseleleri kendisinden beklenmeyen bir tarzda ele aldığını, bunun ise ya konuları gerçek manada kavramasına rağmen saptırmasından ya da yeterli bilgi donanımına sahip olmamasından kaynaklanabileceğini, fakat bütün bunların onun için geçerli olamayacak kadar yetkin bir kimse olduğunu, ancak yine de tökezleme ihtimalinin bulunduğunu söyler. İbn Rüşd, Gazzalî̀nin mezkûr eserinin, onun 
tökezlemesinin bir göstergesi olduğunu ileri sürer. Onun sözü edilen eserini kaleme almasının, yaşadığı dönem ve mekânın gerektirdiği zorunluluktan kaynaklanabileceği ihtimalinin bulunduğunu belirtir (İbn Rüşd, 1986b: 58; 269). Ayrıca İbn Rüşd, Gazzalî̀nin Farabî ve İbn Sina gibi Meşşâî filozoflara yönelttiği itirazların çoğunun birtakım şüphelerden ibaret olduğunu, dolayısıyla eksik bir itiraz niteliği taşıdığını belirtir. Ona göre eksiksiz itiraz, bir kimsenin bireysel görüşüne göre değil de gerçeklere uygun bir şekilde ileri sürülen görüşleri geçersiz kılmayı sağlayan bir nitelikte olmalıdır ((İbn Rüşd, 1986b: 63).

İbn Rüşd, herhangi bir konuda değerlendirme yapabilmek için o konuda uzmanlaşmanın gerekli olduğunu söyler. $\mathrm{O}$, bu hususu te'vil teorisini ortaya koyarken vurgular. Zira ona göre dinî bir hükmün zahiri anlamı burhan yoluyla ulaşılan sonuca aykırı ise onun te'vili araştırılır. Te'vil ise Arapçanın bu konudaki kurallarını ihlal etmeksizin sözün delâlet ettiği manayı gerçek anlamından çıkarıp mecazî anlamına çevirmektir. Te'vili gerektiren hükümlerin yorumlanabilmesi için zahirin iptal edilip, te'vil edilen anlamın ispat edilmesi gerekir. Bu bakımdan te'vil yapabilmek için gereken kuralların çok iyi bilinmesi bir zorunluluktur (ibn Rüşd, 1986a: 35-39; 1992: 76-82). Fakat te'vil konusunda belli bir yetkinliğe ulaşmayan ve dinin maksadını bilmeyen kimselerin yapmış oldukları birtakım yorumlar nedeniyle pek çok problem ortaya çıkmış, neticede aralarında birbirlerini küfürle itham eden fırkalar türemiştir (İbn Rüşd, 1964: 248-251; 1955: 147-150).

Görüldüğü üzere, te'vili gerektiren bir nassın doğru okunup anlamlandırılabilmesi için bu hususta uzman olmak şarttır. Bu bakımdan te'vil konusunda yetkin olmayan bir kimsenin nasları dilediği şekilde anlamlandırma etkinliğinde bulunması dinî açıdan sakıncalıdır. Çünkü bu tür bir uygulama, nassın özünden farklı bir anlamın doğmasına yol açar ki, neticede dinî metin anlam kaymaları sebebiyle aslından giderek uzaklaşıp çok farklı mecralara sürüklenebilir. $O$ halde dinî söylemin kendi bütünlüğü içinde kalarak te'vil yöntemi uygulanmalıdır (Sözen, 2011 : 25).

İbn Rüşd, gerçek bilgiyi elde etmenin tek yolunun kesin delillere başvurmak olduğunu belirtir. Ona göre gerçeği arayan bir kimse, gerçek dışı bir görüşe rastladığında bu niteliği ondan kaldıracak olan güvenilir nitelikte öncüller bulamadığı zaman bunun geçersiz olduğuna hemen hükmetmemelidir. Bu bakımdan söz konusu görüşü ortaya atan kişinin izlediği yol araştırılmalı, bunun için de uzun bir zaman ayrılmalıdır. Ondan sonra da konunun gerektirdiği şartlara göre belli bir yöntem izlenmelidir. Bu durum metafizik alan için çok daha geçerli olmakla beraber diğer bilimler hakkında da söz 
konusudur. O halde metafizik alanda cedelî bir tartışma yersizdir. Diğer bilimlerde ise cedelin kullanılması yasak olmayıp, hatta yararlıdır (İbn Rüşd, 1986b: 113).

\subsection{Her Bilim Dalına Özgü Yöntemleri Kullanma}

Kindî, her bir bilim alanının kendine özgü metodu olduğunu vurgular. Ona göre araştırmacıların çoğu neyi nerede ve nasıl araştıracaklarını bilmediklerinden dolayı yanılgıya düşmüşlerdir. Dolayısıyla o, yanlış yöntem kullanımının olumsuz sonuçlara götüreceğini vurgular. Bazı araştırmacıların ikna, analoji (emsâl), rivayet (ahbâr), duyu (deney) ve ispat metodu (burhân) gibi metotlardan herhangi birini benimseyip kullandıklarını belirtir. Bazılarının ise araştırma yöntemlerine dair bilgilerinin yetersizliği ya da farklı yollardan gerçeğe ulaşmayı arzuladıkları için zikredilen metotların hepsini bir arada kullanmak suretiyle eklektik bir yöntemi benimsediklerini ifade eder. Kindî, hangi alanda ne tür bir metodun kullanılmaması gerektiği hususuna da yer vererek yanlış uygulamanın sonuçlarını dile getirir. Ona göre matematik alanında ikna, metafizikte duyu ve analoji, fizik biliminin ilkelerinde kıyas, belagat sahasında ispat ve ispatın ilkelerine ait bilgilerde ise ispat metodu kullanılmamalıdır. Matematik bilimlerinde ispat metodunun kullanılması gerektiğini belirten Kindî, bu alanda ikna metodunun kullanılması durumunda elde edilen bilginin bilimsel değil, zanna dayalı bir bilgi türü olacağını söyler. $O$, bütün bu şartlara uyulduğu takdirde amaca ulaşmanın daha kolay olacağını, aksi halde hataya düşüleceğini ve elde edilmek istenen neticeye ulaşmakta güçlük çekileceğini belirtir (Kindî, 2014a: 126-127).

Kindî'ye göre algılar, duyu algıları ve aklın algıları olmak üzere ikiye ayrılır. Duyu ve aklın algılarıyla gerçeğe ulaşmak bir yönden kolay, diğer açıdan da zordur. Zira akla göre açık seçik nitelikteki bir bilginin somut kavramını arayan kimsenin durumu, tıpkı yarasanın durumuna benzer. Nasıl ki yarasa Güneş ışığında nesneleri göremiyorsa aklî bir bilginin somut kavramının da görülebilmesi söz konusu değildir. Bu nedenledir ki, metafizik alanda araştırma yapan pek çok kişi metot hatasına bağlı olarak şaşakalmıştır. Fizik alanında (tabiat bilimleri) araştırma yapanlar ise sadece maddî varlıklar alanının dışında geçerli olan matematik metodunu kullandıkları için yanılgıya düşmüşlerdir. Bu bakımdan matematik alana ilişkin metodu fizikte kullanmak yanlış bir uygulamadır. Aksi tutum sergileyen bir araştırmacı ise şaşırır ve gerçeğin bilgisine ulaşamaz (Kindî, 2014a: 133-134).

Düşünür Kindî’ye göre bir bilim dalında araştırma yapanların öncelikle o bilim alanına giren şeylerin sebeplerinin neler olduğunu araştırmaları gerekir. Örneğin, doğal varlıkların sebebinin ne olduğu araştırıldığında bunun değişme (hareket) olduğu görülür. Buradan hareketle tabiatın her türlü değişmenin sebebi olduğu ilkesine 
ulaşılır. O halde tabiî olanın değişikliğe uğraması kaçınılmazdır. Bu bakımdan fizik (tabîiyyât) değişenin, metafizik ise değişmeyenin bilgisini veren alanlardır. Bir şeyin kendisinin sebebi olamayacağı ilkesine göre, değişmenin sebebi değişme, değişenin sebebi de değişen olamaz. Buna göre metafizik bilginin, değişmeyenin bilgisi olduğu açıktır. Kindî, önemli bir yöntem ilkesinin daha altını çizer. Buna göre algılanan her bilginin ispatını istemek gibi bir yola başvurulmamalıdır. Zira her aklî bilginin ispatı yoktur. Bazı şeylerin ispatı mümkün olsa da, her şeyin ispatı imkânsızdır. Çünkü her ispatın ispatı düşünüldüğü takdirde ispat işleminin sonsuza değin sürüp gitmesi söz konusu olur (Kindî, 2014a: 134).

Bilimlerin üstünlük ve değer bakımından birbirinden farklı olduğunu söyleyen Kindî’ye göre, onların en değerlisi felsefedir. Felsefe ise, "insanın gücü ölçüsünde varlığın hakikatini bilmesidir." Filozofun bilgiden gayesi ise gerçeğin bilgisini yakalamaktır. Gerçeğe ulaşıldığında bilgiye ulaşma yönündeki etkinlik sona erer. Fakat sebep bağıntısı olmaksızın gerçeğin bilgisini elde etmek mümkün değildir. Dolayısıyla elde edilen bilgilerin her birinin sebebi bilindiği takdirde onlar mükemmel bir şekilde bilinmiş olur. Her sebep ise ya maddî, ya sûrî (formel), ya fail (hareket ettiren) ya da gaye (tamamlayıcı) olmak üzere dört çeşittir. Bu bakımdan bir varlığın maddî, sûrî ve gaye sebebine ilişkin bilgi edinildiği takdirde onun tanımına ait bilgi de elde edilmiş olur. Her tarif edilene ait gerçeklik ise tarifinde mevcuttur. Bir şeyin maddî sebebine dair bilgi, onun cinsine ilişkin bilgi edinimini de sağlar. Formuna ait bilgi edinildiğinde ise türüne ait bilgi de kazanılır. Türün bilgisi içinde faslın da bilgisi mevcuttur (Kindî, 2014a: 134).

Görüldüğü üzere Kindî, hakikatin bilinmesinin imkânı ile sebep teorisi arasında mutlak bir ilişki kurar. Bu konuda onun Aristoteles'ten esinlendiği anlaşılmaktadır. Zira Aristoteles'in de evrende meydana gelen her çeşit olgunun maddî, sûrî, fail ve gaye sebebi olduğunu ifade ettiği görülmektedir (Aristoteles, 2001: 61-67). Bunun yanı sıra onun, bir şeyin nedeni ile o şeyin hakikatinin bilinmesi arasında mutlak bir ilişki kurduğu, dolayısıyla sebep bilinmeden hakikatin bilinmesinin imkânsız olduğu görüşünü ileri sürdüğü anlaşılmaktadır (Aristoteles, 1985: 993b, 149-150).

Kindî'nin benimsediği dört sebep teorisini Farabî ve İbn Sina'nın da kabul ettiğini görüyoruz. Zira Farabî, bir varlık için dört sebepten söz edilebileceğini belirtir. Bunlar ise maddî, sûrî, fail ve gaye sebeptir (Farabî, h. 1349: 9; 2008a: 8). Benzer düşünceleri İbn Sina da paylaşmaktadır. Ona göre illetler suret, unsur, fail ve gaye olmak üzere dört çeşittir. Bir şeyin varlığının parçası olup, o şeyi bilfiil o şey yapan illet surî illettir. Yine bir şeyin varlığının parçası olmakla beraber o şeyin bilkuvve o şey olmasını sağlayan 
illet ise unsurî illettir. Kendi zatından farklı bir varlık veren sebep de fail sebeptir. Kendisinden ayrı olan bir şeyin varlığının kendisi için meydana geldiği sebep ise gaye sebeptir (İbn Sînâ, 2005: 1). İbn Rüşd de "neden" kavramının fail, suret, madde ve amaç olmak üzere dört nedene ortak olarak verilen bir isim olduğunu söyler (İbn Rüşd, 1986b: 140). O, mevcut varlıkların ise mezkûr nedenlere bağlı bulunduğunu ifade eder (İbn Rüşd, 1986b: 291). Görüldüğü üzere varlık hakkında bilgi edinmenin kendine özgü yöntemleri vardır. Varlığın sebeplerinin bilinmesi, varlığa ait bilgi edinimi sağlar.

Meşşâî ekole mensup düşünürler varlık hakkındaki bilgilerin soruşturulmasına ilişkin metotlar hakkında bilgiler sunmuşlardır. Buna göre ontolojik alanda varlık ile ilgili bilgilerin elde edilebilmesi belli başlı yöntemleri gerekli kılar. Zira varlık hakkında bilgi edinimi temel bazı sorulardan (metâlib) hareketle mümkün olabilir. Bunlar ise "mıdır (hel)" soru eki ve "nedir? (mâ)", "hangisidir? (eyyu)" ve "niçin? (lime)" gibi soru sözcükleridir. Kindî̀ye göre "mıdır (hel)" soru eki sadece bir şeyin varlığını soruşturmaya yönelik kullanılır. Dolayısıyla herhangi bir şeyin var olup olmadığının araştırılması bu ekle mümkün olabilir. Bu soru eki vasıtasıyla bir şeyin doğrudan varlığına yönelik olarak bilgi edinimi amaçlanır. "Nedir? sorusu da her varlığın bir cinsi olduğundan onun cinsini soruşturur. "Hangisidir?" soru sözcüğü ise varlığın faslını (ayrım) soruşturan bir kelimedir. Böylece bir şeyin aynı cins ve türdeki varlıklardan ayırt eden ana karakterinin bilinmesi amaçlanır. Diğer taraftan "nedir? ve "hangisidir?" soru sözcüklerinin birlikte kullanılması, bir varlığın türünün (nev'i) soruşturulmasına imkân verir. "Niçin?" ise varlığın tamamlayıcı (gaye) sebebini soruşturan bir soru formudur. Çünkü mezkûr soru biçimi, mutlak sebebi araştıran bir sorudur. Dolayısıyla bu soru varlığın varlık sebebini, diğer bir ifadeyle var oluş gayesini soruşturmak için kullanılır (Kindî, 2014a: 127).

Varlık hakkındaki bilgi edinme yöntemine ilişkin Kindî'nin sergilediği düşüncelerin Farabî ve İbn Sina'da yansımaları görülmektedir. Zira Farabî'ye göre varlık hakkında bilgi elde etmek için "mıdır (hel)" soru eki ve "nedir? (mâ)", "hangisidir? (eyyu)" ve "niçin? (lime)" gibi soru sözcükleri kullanılır (Farabî, 2008b:133 vd.). Bir şeyin sadece varlığının bilgisine (ilmü enne'ş-şey), varlık sebebine (ilmü lime'ş-şey) ve hem varlığına hem de varlık sebebine ilişskin olmak üzere üç çeşit kesin bilgi vardır. Gerçek bilginin elde edilebilmesi için burhana dayalı olması gerekir. Burhan da üç çeşit olup bunlardan birisi varlık burhanıdır. Bu burhan, bir şeyin varlığının burhanı (burhânu enne'ş-şey) olarak isimlendirilir. Mezkûr burhan ile bir şeyin var olduğunun bilgisi elde edilir. İkincisi ise bir şeyin niçin var olduğunun burhanıdır (burhânu lime'ş-şey) ki, bununla varlığın sebebi hakkında bilgi edinimi sağlanır. Üçüncüsü de mezkûr iki burhanı kapsayan burhan olup, buna da "mutlak burhan" (el-burhân ale'l-ıtlâk) denilir. 
Dolayısıyla bir bilginin burhanî bilgi niteliği taşıyabilmesi için hem varlığa hem de sebebe ilişkin kesinlik taşıması gerekir. Bizatihi bir şeyin varlığının yanı sıra varlık sebebini de veren kesin kıyas, mutlak burhan olarak adlandırılır (Farabî, 2008a: 7).

Düşünür İbn Sina da bir şeyin var olup olmadığının ve varlıkta herhangi bir hâlin bulunup bulunmadığının araştırılmasının "(var) mıdır?" soru ekiyle (matlab-ı hel) gerçekleştirilmesi gerektiğini belirtir. Ona göre "nedir?" sorusu (matlab-ı mâ) ile de bir şeyin mahiyeti soruşturulur. Varlık hakkında "var mıdır/mıdır?" sorusuna verilen cevabın nedeni ise, "niçin?" sorusu (matlab-ı lime) ile araştırılır. "Hangisi?" soru sözcüğü (matlab-ı eyyu) de bir şeyin zâtî niteliklerini ya da özelliklerini ayırt etmek için kullanılır (ibn Sina, 1992: 84-86).

İbn Rüşd'e göre bir meselenin akılla kavranması mümkün değilse bu durumda nakle başvurmak gerekir. Dolayısıyla araştırma konusu yapılan meseleye Kur'an ve Sünnet'in verileri çerçevesinde çözüm aranmalıdır (İbn Rüşd, 1986b: 52). Zira vahiyle elde edilen bilgi, aklî bilginin tamamlayıcısı niteliğini taşır. Dolayısıyla Tanrı, aklın yetersiz kaldığı her şeyi vahiy yoluyla bildirmiştir. Bu bakımdan vahiy bilgisi bütün insanlara Tanrı'nın bir armağanıdır (ỉbn Rüşd, 1986b: 135).

\subsection{Bilimleri Tahsil Ederken Belli Bir Sıralamayı İzleme}

Kindî, bilimlerin belli bir sıra düzenine göre öğrenilmesi gerektiğini, aksi halde arzu edilen bilgi düzeyine erişilemeyeceğini belirtir. Ona göre felsefenin öğrenilmesi için öncelikle matematik kitaplarını okuyup kavramak gerekir. Matematik bilimleri ise aritmetik, geometri, astronomi ve te'liftir (müzik). Matematik bilimlerinden yoksun olan bir kimsenin Aristoteles'in kitaplarını anlaması, içerdiği bilgileri tam anlamıyla elde edip kavraması imkânsızdır. Mezkûr nitelikteki kişi ezber metodunu kullansa bile bu yöndeki çaba ve kazancı bilgi aktarmaktan, yani rivayetten öteye geçemez, dolayısıyla bununla sınırlı kalır. Bu bakımdan matematik bilgisinden yoksun olunduğu takdirde Aristoteles'in ortaya koyduğu bilgilerin özüne vâkıf olabilmek imkânsız bir hale gelir. Matematik bilimlerinin ilki, sıra düzeni, sonuç vermesi ve öncelik hakkına sahip olması yönünden aritmetiktir. İkincisi ise geometri olup, ispata dayanır. Zikredilen alandaki bilimlerin üçüncüsü astronomi, dördüncüsü de müziktir (Kindî, 2014b: 272, 278).

Düşünür Kindî'ye göre bir kimsenin filozof olabilmesi için matematik biliminden sonra Aristoteles'in birbirinden müstakil olmakla beraber birbirinin tamamlayıcısı konumundaki kitapların toplamından ibaret olan Organon adlı mantık külliyatı tertip edildiği şekle göre okunmalıdır. Daha sonra ise fizik, psikoloji, metafizik, ahlak ve siyaset ile ilgili kitapların okunması gerekir. Bunları müteakiben de zikredilen bilimlere dayalı diğer 
bilimlere ait bilgiler elde edilmelidir. Dolayısıyla yönteme bağlı hareket edildiğinde insanın son yetkinliğe ulaşmasını sağlayacak olan bilim elde edilmiş olur. Bilimler ise insanın kendi talebine ve çabasına bağlı olarak belli aşamalardan geçmek suretiyle elde edilir. Fakat bilimlerin içerdiği bilgiler mertebe bakımından ilahî bilgiden yani vahiy bilgisinden aşağıdadır. Tanrı'nın peygamberlere özgü kıldığı bilgi bu tür bir bilgidir ki, çaba harcama, araştırma yapma, matematik ve mantıkî ilkelere başvurma olmaksızın zamansız oluşan bir bilgi türüdür. Bu bilgi Tanrı'nın peygamberlerin nefsini temizleme ve aydınlatmayı dileyerek O'nun desteği, ilhamı ve vahyi ile gerçekleşir. Dolayısıyla vahiy bilgisi, insanların benzerini ortaya koymaktan aciz olduğu bilgi olup, gerçekliği sabittir (Kindî, 2014b: 269-274, 279).

Farabî de felsefe öğreniminde takip edilmesi gereken metotlardan bahseder. O, mezkûr konuda Aristoteles'in fikirlerinin temel olarak alınması suretiyle dokuz husustan söz eder. Bunlar ise, sırasıyla felsefî okulların adları, Aristoteles'in kitaplarındaki gaye, felsefe öğrenimine başlamadan önce kavranması gereken disiplinler, felsefe öğrenmedeki amaç, felsefe yapmak istenildiğinde takip edilecek metot, Aristoteles'in kitaplarının üslubu, onu zor üslup kullanmaya yönelten nedenler, felsefe yapan kimsenin takınacağı tutum ve davranış ile Aristoteles'in kitaplarını okumak isteyen kişinin öğrenmesi gereken bilgiler gibi hususlardan ibarettir (Farabî, 1890: 49; 2003: 109).

Felsefe öğreniminden önce tahsil edilmesi gereken bilimler hakkında bilgiler sunan Farabî, ilk olarak hangi bilimden başlanacağı ile ilgili farklı görüşlerin ileri sürüldüğünü belirtir. Bu konuda bazılarına göre öncelikle geometrinin, bazıları açısından da ahlak biliminin elde edilmesi gerekir. Bunun yanı sıra fizik biliminin öncelikle okunması gerektiğini söyleyenler olduğu gibi, mantıktan başlanılmasını ileri sürenler de mevcuttur. Farabî ise bu görüşlerin hepsinin dikkate alınmasını önerir. Zira Farabî'ye göre felsefe öğrenmeye başlamadan önce nefsin şehevî arzularını yenerek ahlakın olgunlaştırılması gerekir. Bu durum ise arzu ve eğilimlerin yalnızca erdeme yönelmesini sağlar. Dolayısıyla erdem, ahlakı iyileştirmekle elde edilir. Felsefeye başlamak isteyen kişi ahlak bakımından belli bir yetkinliğe ulaştıktan sonra zihin gücünü (en-nefsü'nnâtıka) geliştirmek zorundadır. Zira zihnin yanılmasını ve yanlış yola sapmasını engelleyen doğru metot bu sayede öğrenilir. Bu ise "burhan ilmi"ni öğrenmekle gerçekleşir. Burhan da geometrik ve mantıkî olmak üzere ikiye ayrıldığına göre, felsefe öğretimine başlamadan önce yeterli düzeyde geometrik ispat şekilleri ve daha sonra da mantık konusunda eğitim alınması gerekir. Felsefe yapmak isteyen kişinin takip etmesi gereken metot ise pratiğe yönelmek suretiyle en son gayeye ulaşmaktır. Pratiğe yönelmenin yolu da bilimdir. Fizik bilmeden en son amaca ulaşılamaz. Çünkü fizik, en 
kolay anlaşılabilecek bir alandır. Fizik biliminin ardından ise geometri gelir. Pratikte hedeflenen en son gayeye ulaşmak ise öncelikle insanın kendi ahlakını, daha sonra da ev halkını veya yaşadığı toplumu ahlakî bakımdan olgunlaştırıp düzeltmesiyle gerçekleşebilir (Farabî, 1890: 52-53; 2003: 113-114).

Düşünür İbn Sina da bilimlerin belli bir sıraya göre öğrenilmesi gerektiğini belirtir. Ona göre bütün bilimler tek bir faydada ortaktırlar. Bu husus ise insan nefsini, bilfiil yetkinliğini sağlamak suretiyle uhrevî mutluluğa hazırlamaktır. Metafiziğin bilimler arasındaki mertebesi, doğa ve matematik bilimlerinden sonra öğrenilmesidir. Onun doğa bilimlerinden sonra öğrenilmesinin nedeni ise oluş-bozuluş, değişme, mekân, zaman ve hareket gibi metafizikte yer alan meselelerin çoğunun doğa biliminde (fizik) açıklanan hususlar olmasıdır. Metafiziğin matematik bilimlerinden sonra öğrenilmesinin nedeni de metafizikte hedeflenen nihai amaca ancak bu bilimler arasında yer alan astronomi bilimi ile ulaşımasının mümkün olmasından kaynaklanır. Zira Tanrı'nın evreni idare etmesi (tedbir), ruhanî melekler ve onların tabakalarının yanı sıra feleklerin dizilişindeki düzen ile ilgili bilgilere sadece aritmetik ve geometri bilimleriyle ulaşmak mümkündür. Müzik, matematiğin alt dalları, ahlak ve siyaset ise metafizik açısından yararlı olmakla beraber zorunlu olmayan bilimlerdir (ibn Sina, 2004: 17).

Görüldüğü üzere Meşşâî filozoflar bilimlerin hangi sıralamaya göre tahsil edilmesi gerektiği hususunda birtakım pedagojik ilkelerden bahsetmişlerdir. Onların yaşadığı dönemler itibarıyla önem taşıyan bu ilkeler, gerçek bilgiyi elde etme ve gerekli bilgi donanımını kazanma açısından bugün de değerini korumaktadır. Çünkü eğitim ve öğretimde belli bir plan ve programı takip etmek suretiyle hareket edilmesi, hedeflenen amaç ve kazanımlara ulaşılması açısından önem taşımaktadır.

Sonuç itibarıyla metot bilgisi, bilgi edinme sürecinde gerçeği bulup ortaya çıkarmak veya bilinen bir hakikati ispat etmek için son derece önemlidir. Bilimlerin oluşumunda ve gelişiminde bilimsel bilgi temel unsurdur. Dolayısıyla bu tür bir bilgi edinimi için belli başlı metodik ilkelerin dikkate alınması bir zorunluluktur. $O$ halde bilgi elde etmedeki hedeflerin çok iyi belirlenmesi, geçmişteki tecrübe ve birikimlerden yararlanılması ve bilimsel bakımdan taassuptan uzak bir tavır sergilenmesi suretiyle birtakım yeni bilgiler üretmek, bilimde yenilik ve ilerlemenin sağlanabilmesi açısından mutlak bir değer ifade eder. Arzulanan neticeye ulaşmak ise belli bir çabayı gerektirir. $\mathrm{Bu}$ bakımdan başkalarının emeklerine yaslanarak eldeki mevcut bilgi birikimleriyle yetinmek, bilimsel açıdan yenilik ve ilerlemenin önündeki en büyük engeldir. Öyleyse asıl olan, bir meyve ağacının altına düşen hazır meyveyi toplayıp elde etmek değil, aksine ağaca tırmanmak suretiyle istenilen meyvenin bizzat dalından koparılıp 
devşirilmesidir. Çünkü zikredilen bu iki durum arasında büyük ölçüde fark vardır (elIrakî, 2009: 18). Bu bakımdan geçmişten bize tevarüs eden metodik ilkeleri göz önünde bulundurarak yoğun bir şekilde bilgi üretme etkinliğinin sürdürülmesi gerekir. Bilimlerin gelişmesi ise ancak bu sayede mümkün olabilir.

\section{Sonuç}

Bilgi edinme sürecinde metodik ilkeler son derece önemlidir. Çünkü metot, gerçek bilgiyi elde etmek için yol gösterici bir niteliğe sahiptir. Bu bakımdan metot bilgisi ile gerçek bilgiyi edinme arasında mutlak bir ilişki mevcuttur. Zira düzensiz ve kuralsız yapılan araştırmaların sonucunda sadece bilimsellikten uzak bilgi yığınları elde edilebilir. O halde gerçek bilgiyi kazanabilmek için, gerekli olan bazı metodik prensiplere göre hareket edilmesi bir zorunluluktur.

Meşşâî felsefe geleneğine mensup düşünürler gerçek bilginin elde edilebilmesi için birtakım metodik ilkeleri benimsemişlerdir. Bu çerçevede Meşşâî ekolün kurucusu kabul edilen Kindî'nin metot ile ilgili görüşler serdetmesi son derece önemlidir. Zira bu husus hem kendi düşünce sistemini inşa etmesi hem de kendinden sonra gelen düşünürlere kaynak olması bakımından bir değer ifade eder. Keza Kindî'nin metot ile ilgili görüşlerinin Farabî, İbn Sina ve İbn Rüşd gibi filozoflarda da yansımalarını görmek mümkündür.

Geçmişten günümüze tevarüs eden metotla ilgili prensiplerin çok iyi kavranması gerekir. İsimleri mezkûr Meşşâî filozofların dikkat çektiği gibi, hangi bilim dalında ne tür metotların geçerli olduğunun bilinmesi, gerçek bilgiye ulaşma açısından önemli bir keyfiyettir. Bu bakımdan bilgi edinim sürecinde metodik ilkeler doğrultusunda hareket etmeyi, hakiki bilgiyi kazanabilmenin temel şartlarından birisi olarak değerlendirmek mümkündür.

Sonuç olarak, bilimsel açıdan ilerlemek için geçmişin bilgi birikimi ve tecrübelerinden istifade edilmeli, bağnazlığa ve dogmatizme yol açacak olumsuz tavırlardan uzak durulmalıdır. Hz. Peygamber'in bilim ve hikmeti elde etme konusundaki tavsiyesi göz önünde bulundurulmalı, kimden ve nereden gelirse gelsin, hakikatin bir değer ifade ettiği hususu unutulmamalıdır. Bilimsel tenkit ve değerlendirmeler ise objektif ölçütler çerçevesinde yapılmalıdır. Bilgi açısından sürekli yenilenmek ve yeni sonuçlar elde etmek vazgeçilmez bir hedef olarak görülmelidir. Bilgisizliğin karanlığından aydınlığa çıkmanın, geleceği doğru bir şekilde planlamanın, bilim ve teknolojik bakımdan kalkınma ve ilerlemenin temelinde bilimsel bilginin yer aldığı gerçeği dikkate alınmalı, 
hedeflenen gerçek bilgiyi elde etmek için metodik birtakım ilkeler benimsenmek suretiyle o çerçevede hareket edilmelidir.

\section{Kaynaklar}

Aristoteles, (2001). Fizik, (Çev. S. Babür). İstanbul: Yapı Kredi Yayınları.

Aristoteles, (1985). Metafizik, c. 1 (A-Z), (Çev. A. Arslan). İzmir: Ege Üniversitesi Basımevi.

Bayrakdar, M. (2011). Islam Felsefesine Giriş. Ankara: TDV Yay.

Beyhakî, Ahmed b. el-Hüseyin (2003). Şuabu'l-iman. c. 3, (thk. A. A. Hânid). Riyad: Mektebetü'rRüşd.

Descartes, (1997). Aklın Idaresi Için Kurallar. (Çev. M. Karasan). İstanbul: MEB Yayınları.

el-Irakî, Â. (2009). el-Felsefetü'I-Arabiyye ve't-tarîk ile'l-müstakbel. Kahire: Daru'l-irşâd.

Farabî, (h. 1349). ed-Deâva'l-kalbiyye. Haydarabad: Meclisu Daireti'l-Maarifi'l-Osmaniyye.

Farabî, (2008a). Kitâbu'l-Burhân, (Çev. Ö. Türker-Ö. M. Alper). İstanbul: Klasik Yayınları.

Farabî, (2008b). Kitâbu'l-Hurûf, (Harfler Kitabı). (Çev. Ö. Türker), İstanbul: Litera Yayıncılık.

Farabî, (1890). Risâle fimâ yenbağ̂̀ en yukaddeme kable te'allümi'l-felsefe, es-Semeretü'lmerdıyye içinde (nşr. Friedrich Dieterici). Leiden-E.J. Brill.

Farabî, (2003). Risâle fimâ yenbağ̂̀ en yukaddeme kable te'allümi'l-felsefe, (Felsefe Ögrreniminden Önce Bilinmesi Gereken Konular), (Çev. M. Kaya), İsâm Filozoflarından Felsefe Metinleri (haz. M. Kaya) içinde. İstanbul: Klasik Yayınları.

Farabî, (1974). Tahsîlu's-saâde (Mutluluğu Kazanma), (çev. Hüseyin Atay), Farabî'nin Üç Eseri içinde. Ankara: AÜ ilâhiyat Fakültesi Yayınları.

Farabî, (2012). Tahsîlu's-saâde, (Nşr. S. el-Hevvârî). Beyrut: el-Mektebetü'l-asriyye.

İbn Mâce, Ebû Abdullah, (1981). Sünen. İstanbul: Çağrı Yayınları.

İbn Rüşd, (1992). Fas/u'l-Makâl (Felsefe-Din Ilişskisi), (Çev. B. Karlığa). İstanbul: İşaret Yayınları.

İbn Rüşd, (1986a). Fas/u'l-makâl, (Nşr. A. N. Nâdir). Beyrut: Daru'l-Meşrık.

İbn Rüşd, (1955). Kitâbu'l-Keşf an menâhici'l-edille (Çev. N. Ayasbeyoğlu), N. Ayasbeyoğlu, ibn Rüşd'ün Felsefesi içinde. Ankara: TTK Basımevi.

İbn Rüşd, (1964). Kitâbu'l-Keşf an menâhici'l-edille fí akâidi'l-mille, (Thk. Mahmut Kasım). Kahire.

İbn Rüşd, (1986b). Tutarsızlığın Tutarsızlığı (Tehâfüt et-Tehâfüt), (Çev. K. Işık-M. Dağ). Samsun: Ondokuz Mayıs Üniversitesi Yayınları.

İbn Sina, (1992). en-Necât, cüz' 1, (Mantık Bölümü), (Thk. Abdurrahman Umeyra). Beyrut: Daru'lCîl.

İbn Sina, (2004). Kitâbu'ş-Şifa, Metafizik I, (Çev. E. Demirli-Ö. Türker). İstanbul: Litera Yayıncılık. İbn Sina, (2005). Kitâbu'ş-Şifa, Metafizik II, (Çev. E. Demirli-Ö. Türker). İstanbul: Litera Yayıncılık. İsmail Fenni (h. 1341). Lügatçe-i Felsefe. İstanbul: Matbaa-i Âmire.

İsmail Hakkı (İzmirli), (h. 1329). Fenn-i Menâhic: Méthodologie. Dersaadet: Hukuk Matbaası.

Kaya, M. (2004). "Meşşâiyye", DiA, c. 29, Ankara. 393-396.

Kindî, (2014a). fi'l-Felsefeti'l-ûlâ (illk Felsefe Üzerine). Kindî, Felsefí Risaleler (Çev. M. Kaya) içinde. İstanbul: Klasik Yayınları. 
Kindî, (2014b). Risâle fî Kemmiyyeti kütübi Aristûtâlîs ve mâ yuhtâcu ileyhi fi tahsîli'l-felsefe (Kindî'nin Aristoteles'in Kitaplarının Sayısı ve Felsefe Tahsilinde Buna Duyulan Ihtiyaç Konusunda Risalesi). Kindî, Felsefî Risâleler (Çev. M. Kaya) içinde. İstanbul: Klasik Yayınları.

Sarıoğlu, H. (2003). İbn Rüşd Felsefesi. İstanbul: Klasik Yayınları.

Sözen, K. (2005). "Kindî'nin Metot Anlayışı", Tabula Rasa. 5/14, Isparta. 21-31.

Sözen, K. (2011). "Din-Felsefe İlişkisi Bağlamında Dinin Günümüz Türkiye'sinde Yorumlanması Sorunu", SDÜ ilahiyat Fakültesi Dergisi. 26, Isparta. 17-31.

Tirmizî, Ebû İsa, (1981). Sünen, İstanbul: Çağrı Yayınları.

Yücel, H-Â. (1948). Bilimler Felsefesi, Mantık, İstanbul: Milli Eğitim Basımevi. 